\title{
The Guidelines of Corporate Governance of Ghana: Issues, Deficiencies and Suggestions
}

\author{
Otuo Serebour Agyemang ${ }^{1} \&$ Monia Castellini ${ }^{1}$ \\ ${ }^{1}$ Department of Economics and Management, University of Ferrara, Italy \\ Correspondence: Otuo Serebour Agyemang, Department of Economics and Management, University of Ferrara, \\ Via Voltapaletto 11, Ferrara. Tel: 39-348-9921-968. E-mail: otuo.serebour.agyemang@gmail.com
}

Received: May 29, 2013

Accepted: August 2, 2013

Online Published: September 23, 2013

doi:10.5539/ibr.v6n10p163

URL: http://dx.doi.org/10.5539/ibr.v6n10p163

\begin{abstract}
The worldwide mushrooming of codes of corporate governance has resulted in a formalisation of rules and norms. These rules and norms have undeniably been proven to be important constituents in shaping the present corporate governance structures across the globe. The 2010 Code of best practices for corporate governance issued by the Securities and Exchange Commission of Ghana is an archetypical of such codes. It is irrefutably the most encyclopaedic guideline for good corporate governance practices presently in Ghana. It contains overarching provisions for effective corporate governance practices in Ghana. This paper presents a painstaking review of the code. It first examines key properties of the code. Next, the main deficiencies of the code are illuminated by examining the provisions that lack clarity. Also, other unqualified derelictions, substandard provisions and common gaffes in the code are highlighted. It then makes suggestions with the idea that they would be taken into consideration if future remediation of the code is to be undertaken.
\end{abstract}

Keywords: code of best practices, corporate governance, issues, deficiencies, suggestions, independent non-executive directors, executive directors, Ghana

\section{Introduction}

\subsection{Introduction to Problem}

The importance of good corporate governance has currently taken international dimensions. The revelations of corporate frauds, excessive compensation packages and scandals around the globe have made capital providers and other corporate stakeholders to become aware of the immeasurable advantages good corporate governance practice can offer. Countries and global institutions across the length and breadth of the globe have drawn codes of best practices to make sure that good corporate governance prevails in their economies and the world at large. Examples of these codes are Indonesian code of good corporate governance, the stock exchange code of Republic of Korea, OECD principles of corporate governance, CACG guidelines, SEC code of Pakistan, corporate governance code of Romania, Code of corporate governance in Nigeria and so on. These codes are commonly considered as guidelines aimed at fostering capital market evolution by increasing transparency in corporate organisations and the level of equity holder protection (Cankar, Deakin, \& Simoneti, 2010). However, these codes of good corporate governance have their strengths and weaknesses. And these have prompted an in-depth examination of the various guidelines in corporate governance codes around the world.

The mushrooming of codes of corporate governance across the world clearly explains the importance of corporate governance. It is a significant development for both corporate organisations and capital providers because codes formalise the rules and structures that are aimed at guiding corporate organisations. They offer some sort of accountability and reliability in corporate affairs (Huse, 2007). Also, they have been proven to be useful in so many ways. For instance, they have stimulated the global discussion on corporate governance, induced corporate organisations to adhere to commonly-accepted governance-standard, assisted in explaining governance-related legal requirements as well as widely-accepted practices of corporate governance to capital providers, aided in preparing the foundation for modifications in company laws (where such modifications are considered indispensable) and so on (EU, 2002; Haskovec, 2011).

The code of best practices on corporate governance in Ghana 2010, released by the Securities and Exchange Commission of Ghana is undisputedly regarded as the most encyclopaedic guideline for corporate governance 
practices in Ghana presently. Because of its extensive and catholic nature, there is little or no doubt that good corporate governance can be deepened in Ghana if corporate organisations adhere to its suggested guidelines. It was released to augment the already existing guidelines for good corporate governance namely; companies code 1963 (Act 179), Securities Industry Laws, 1993 (PNDCL 333) as revised by the Securities Industry Act, 2000 (Act 590) as well as the listing regulations, 1990 (L. I. 1509) of Ghana Stock Exchange (GSE).

The code was issued by the Securities and Exchange Commission (SEC) to corporate entities licensed under the Securities Industry Laws and the issuers of publicly listed securities specifically, those traded on stock exchanges. Its creation was essentially aligned with the principles of good corporate governance by the Organisation of Economic Cooperation and Development (OECD, 2004), the Commonwealth Association of Corporate Governance (CACG, 1999) and codes of best practices put forth by regulatory bodies in emerging and transition economies. It is basically designed to serve as "guidelines whereby the standards of governance in corporate bodies regulated by the Commission may be benchmarked" (Ghana, 2010). Further, the code is anticipated to be the minimum corporate governance guidelines required of publicly-traded corporate organisations in Ghana. Aside this code, there are other two corporate governance guidelines that are in operation in Ghana: 1) the Ghana National Accounting Standards and Principles (GNASP), and Codes of professional conduct by the Institute of Chartered Accountants, Ghana (ICAG) - which are aimed at ensuring good corporate governance practice; 2 ) the manual on corporate governance of Ghana, which was sponsored by the International Finance Corporation (IFC) and designed by Fintra consult, Ghana, Carl Bro Management, Denmark, and African Management Services Company (AMSCO), the Netherlands.

A substantial amount of studies has been conducted on codes of corporate governance on country-by-country basis to ascertain their strengths and deficiencies, and to suggest ways to curtail their deficiencies in order to improve corporate governance practices in these economies and the world in general (Cankar, et al., 2010; Haskovec, 2011; Heracleous, 1999; Ofo, 2011; Werder \& Talaulicar, 2011). In 2012, Haskovec carried out a review on codes of corporate governance in Europe and the US. Similar study was conducted in 2011 by Ofo on the code of corporate governance in Nigeria by benchmarking the code against ten international best practices. Werder and Talaulicar in 2011 carried out a study on corporate governance in Germany by examining the basic characteristics of the German corporate governance code. Furthermore, Cankar, Deakin and Simoneti in their study in 2008, reviewed the properties of corporate governance codes in Slovenia. Notwithstanding these substantial studies on codes of corporate governance across the globe, most developing and transition economies are still lagging behind. But it is imperative that studies on the codes of corporate governance of these economies would help them identify the strengths and weaknesses associated with their codes and to find ways to improve them. Therefore, this paper aims at partially filling this research hiatus by examining the 2010 SEC code of best practices of Ghana. It presents an extensive review of the provisions of the code. It first examines the key properties of the code such as issues pertaining to boards, shareholders, auditors and other stakeholders. Next, the main deficiencies of the code are illuminated by examining the provisions that lack clarity. Also, other unqualified derelictions, substandard provisions and common gaffes in the code are highlighted. Then it concludes with some suggestions with the idea that they would be taken into consideration if future revision of the code is to be undertaken.

The remainder of the paper is structured as follows: Section 2 presents the methodology of the paper. Analysis of the 2010 SEC code is presented in section 3, by highlighting the issues, deficiencies and suggestions of the code. Finally, section 4 concludes the paper with some recommendations.

\section{Methodology}

The amount of resources concerning corporate governance is substantial and on the increase across the world. Notwithstanding these resources, several laws, listing requirements and regulations across the globe deal with this issue extensively. The present development of corporate governance guidelines globally, is tended to focus on corporate governance practices to ensure that corporate organisations are run effectively and held accountable in the use of corporate resources (EU, 2002). In order to thoroughly examine the 2010 SEC code and bring out the issues and deficiencies embedded in it, the following methodology was applied.

- Preliminary identification of the code: A search for the code took the researchers to the website of European Corporate Governance Institute (ECGI) where a catalogue of all codes across the world is available. Opportunely, the researchers were able to get the code from the website.

- The researchers then consulted the Securities and Exchange Commission of Ghana to verify the authenticity and completeness of the code. This was done to enhance the reliability of the study. 
- Code analysis: The code was then analysed to ascertain the main governance-related issues and the deficiencies associated with it. The governance related issues that were spotted in the code and were examined concerned board-related issues, shareholder-related issues, other stakeholder-related issues and audit-related issues. The deficiencies associated with the code were grouped into four main subheadings: provisions that lack clarity; substandard provisions, unqualified derelictions; and common gaffes.

- Terminology: It should be noted that some terms were used interchangeably in this paper. For example, 'board member' was sometimes used to refer to 'director'. Also, 'stockholders', 'equity holders' and 'shareholders' were used interchangeably. Non-executive director was sometimes referred in this paper as 'outside director' or 'non-executive member'.

\section{Code Analysis}

\subsection{Key Features of the 2010 SEC Code}

This section of the paper is addressed under four broad sub-sections as provided in the 2010 SEC Code: 1) Board-related issues- the separation of the roles of the CEO and Board chairperson, the responsibilities of the board, the responsibilities of the board chairperson, definition of independent directors, financial literacy of members of audit committees, annual performance assessment of the board, its committees, chairperson and individual directors, and company secretary; 2) Shareholder-related issues 3) Stakeholder involvement; and 4) Audit-related issues.

\subsubsection{Board-Related Issues}

As a result of the relevant role boards of directors play in insuring good corporate governance in corporate organisations, it is not all that astonishing to note that the 2010 SEC code of best practices focuses on the board as the main governance mechanism to ensuring effective corporate governance. First and foremost, the code provides for a split of the roles of the CEO/Managing director and that of the Board Chairperson of the same corporate organisation. Accordingly, Section i (14) provides that preferably, the position of the Board Chairperson ought to be separated from that of the Chief Executive Officer of the corporate organisation unless there are particular explanations that go against such schism or as perhaps will be in the situation of smaller firms where such separation will be economically imprudent as a result of the cost associated with such division. In order to clarify the various roles of these topmost positions in a company, section i (18) provides that the chairperson ought to insure that the board is in absolute control of the affairs of the corporate organisation and attentive to the responsibilities to equity holders, industry, and the legal and regulatory framework. Although the code does not clearly specify the role of the CEO, section i (16) provides that in the situation where there is a split of these two roles, their specific roles and responsibilities should be lucidly itemised.

Many corporate governance experts stress that it is crucial that the positions of the CEO/Managing director and the Board chairperson are split to ensure checks and balances. This approach is widely applied in the United Kingdom and other economies, particularly Commonwealth countries. Larcker and Tayan (2011) argue that corporate organisations that split up the roles of these two topmost positions stand the chance of benefiting. This is because, with this separation, corporate organisations can: unambiguously spell out the responsibilities of these two topmost positions; do away with conflicts in regards to CEO performance assessment, compensation packages for executives, recruitment of independent directors and long-term succession planning; and gives the CEO enough time to concentrate utterly on the corporation's business strategies, operations and culture (Larcker \& Tayan, 2011). Millstein and McAVoy (2003) advocate that the separation of the two positions with an independent director as chairperson is germane to position the board as an objective monitoring and controlling mechanism. Pease and McMillan (1993) also postulate that in order to ensure objectivity by avoiding concentration of power in the hands of one individual, there is the need to separate the roles of the board chairperson and the CEO. The combination of the roles of the chairperson and CEO will lead to a compromise (finding the middle ground) between them, but their separations will enrich the board's independence while monitoring the CEO. Berghe and Levrau (2004) support the argument that agency theory endorses this separation thus reducing the supremacy of management over the board.

Even though the concept of a non-duality structure has been discussed for decades, it is only in recent times that it received attention as a practice from many countries. For instance, most companies in the US such as Aon, intercontinental hotels, Tenet Healthcare and Walt Disney Company have non-executive chairpersons. The major arguments in favour of this idea stems from the assertion that separating the two positions and selecting a non-executive chairperson will heighten the capability of the board to monitor and control the actions of the $\mathrm{CEO}$ as well as to function independently. Also, with the split of these two positions, the board has a leader who is free from any interference that is considered to mar its solitary mandate to act effectively. This idea makes 
directors to feel more comfortable to act boldly to challenge the CEO on some decisions that are likely to affect the company. Furthermore, more often than not, capital providers prefer investing in companies with non-executive chairpersons, and because of that, companies that have this type of system attract a lot of investors. Countries such as Germany, Switzerland, Holland and the Scandinavian countries have these two positions (CEO and chairperson) separated by law.

The split of these vitally important roles is not something new in Ghana in that this practice has been in existence for quite some years now. The companies code 1963 (Act 179), Securities Industry Laws, 1993 (PNDCL 333) as amended by the Securities Industry Act, 2000 (Act 590), SEC regulations, 2003 (L. I. 1728) as well as the listing regulations, 1990 (L. I. 1509) of Ghana Stock Exchange (GSE) provide for the separation of these two positions. However, the most planned with painstaking provision on this issue in Ghana is furnished in the 2010 SEC code. This is in line with the best business practices across the globe.

Secondly, the 2010 SEC code clearly states the responsibilities of board of directors. It is pleasing that the code has overtly enumerated the objectives and responsibilities of boards of corporate organisations. Accordingly, Section i (1.a) clearly provides that the main function of the board of a company is to make sure that the firm is well-administered in order to safeguard and improve the interests of shareholders and to fulfil the corporation's responsibilities to its equity holders, the industry in which it operates, and the legal and regulatory framework. Also, it provides the primary responsibility of the board by spelling out that the board's responsibility is to make sure that its board members are abreast with the tenets of good corporate governance (Ghana, 2010). Furthermore, section i (3) of the 2010 SEC code itemises the principal duties of the board of directors to include: ensuring strategic guidance of the corporate organisation in keeping up with its business goals; supervising the management and conduct of the corporate organisation; identifying risk and implementing strategies to manage it; succession planning and the appointment, training, compensation and replacement of top management; supervising internal control systems; and maintenance of the corporate entity's communication and information dissemination policy/programme (Ghana, 2010).

It is informative that section (2) of the code spells out the basic responsibility of the board; that it has to insure that good corporate governance prevails in the corporate organisation. In that case, the implication is that the board must not only insure that they operate in conformity with the tenets of effective corporate governance in their day to day operations, but must also make sure that the tenets of effective corporate governance are in operation throughout the corporate organisation.

Thirdly, the code clearly states the responsibilities of the board chairperson. Section i (17) highlights that the board chairperson should play an important role in securing good corporate governance within the corporate organisation. Also, the chairperson should insure that the board is in absolute control of the affairs of the company and completely aware of its responsibilities to stockholders, industry, and the legal and regulatory framework. The code further points out the functions of the board chairperson, which shall include; ensuring that the board meetings are frequent and that meetings are carried out in an appropriate manner; ascertaining the opinions and/or the decision of the gathering on the matters being deliberated; ensuring that board members are incentivised to offer their specific potentials so as to secure the utmost benefit for the firm; being liable for board members receipt of information; and ensuring that any outside director who is not making any meaningful contribution to board discussions is either not reelected or asked to relinquish his/her membership or is fired (Ghana, 2010). Section i (20) also points out that the board chairperson should strive to ensure that the board institutes a mechanism for evaluating board effectiveness, the contributions of individual directors and the various committees of the board.

The provisions of the code on the roles and responsibilities of the board chairperson are praiseworthy in that they are in line with international best practices. It is worth noting that Section i (17-19) of the code clearly states an incontrovertible job description for a board chairperson and would offer as a point of reference for potential board chairpersons and a suitable memory stimulant for present chairpersons in corporate organisations in Ghana.

Fourthly, the code unambiguously defines who an independent director is. Much emphasis has been placed globally on the role independent non-executive directors play in ensuring effective corporate governance. Currently, Italy's corporate governance code, 2011, is debatably considered to be the only code that comprehensively defines who really an independent director is. Section 3.C.1 of Italy's corporate governance Code states that "the Board of Directors shall evaluate the independence of its non-executive members having regard more to the contents than to the form and keeping in mind that a director usually does not appear independent in the following events..." if the person controls, directly or indirectly, the issuer via subsidiaries, 
trustees or third parties, or is able to exert over the issuer paramount influence, or partakes in a stockholders' agreement through which one or more individuals can exert a control or paramount influence over the issuer; if the individual is, or has been in the previous three fiscal years, a substantial representative of the issuer, of a subsidiary having strategic relevance or of a corporation under common control with the issuer, or of a corporation or entity controlling the issuer or able to exercise over the same a significant influence, also jointly with others via a stockholders agreement; if the individual has, or had in the previous fiscal year, directly or indirectly a substantial commercial, professional or financial connections with the issuer, its subsidiaries, or any of its major representatives, or has been in the previous three fiscal years, a worker of the issuer, its subsidiaries or its major representatives; if the individual receives, or has received in the previous three fiscal years, from the issuer or a subsidiary or holding corporation of the issuer, a considerable extra remuneration; if the individual was a director of the issuer for not at least nine years in the last twelve years; if the individual is vested with the executive director office in different corporate organisation in which an executive director of the issuer holds the office of director; if the individual is stockholder or quotaholder or director of a legal company belonging to the same network as the firm selected for the auditing of the issuer; and if the person is a close relative of an individual who is in any of the positions listed above (Italy, 2011).

Section i (23) of the 2010 Code has somewhat addressed the fundamental challenges pertaining to director independence definition. Juxtaposing the definition provided in the Italian corporate governance code regarding director independence definition with that of the 2010 SEC code of Ghana, it can be deduced that the 2010 SEC Code does not exhaustively provide the definition of director independence as witnessed in Italy's corporate governance code. For instance, the director tenure and additional remuneration are not exhaustively dealt with by the 2010 SEC Code.

Fifthly, the issue regarding the establishment of an audit committee is explicitly stated in the code. Section i (46) lucidly states that every corporate organisation at which this code is geared toward should strive to set up an audit committee. The main duties of the board audit committee are also unambiguously itemised. Also, the authority of the committee is overtly enumerated in the code. For instance, the audit committee should; have the authority to carry out an investigation on any issue under its terms of reference; be furnished with the necessary and sufficient resources it needs to conduct such investigation; and be provided with full access to necessary and sufficient information (Ghana, 2010). Furthermore, Section ii (53) extends the committee's authority by stating that it ought to, with the consent of the board be able to solicit for outside expert counsel as and when the need arises. One aspect that the code lucidly tackles is the adequacy of knowledge of committee members. Section ii (48) of the code unequivocally states that members of the audit committee should preferably be made up of directors with sufficient knowledge in finance, accounting and the fundamental elements of the rules and regulations within which the firm runs. This is extremely relevant in that, if committee members perform their functions and authorities appropriately, the committee could play an auxiliary role in helping the board to execute its monitoring and controlling functions over the financial and accounting statements of the concerned corporate organisation.

Sixthly, the issue of director orientation and education is lucidly addressed in the code. Currently, board directors are faced with gargantuan challenges. These challenges are as a result of the growing number of shareholders' activism, varied backgrounds of board directors, changes in the environment they operate, practical changes of relevant regulations and shareholder growing knowledge about how corporations are to be governed. Since orientation to a new job is significant for optimal performance (Huse, 2007), corporations should make sure that upon director appointment, directors are ushered into the corporate organisation to make them aware of all the nitty-gritty in regards to how boards operate. Also, it is relevant for board directors to take on refresher courses and training to make them become abreast with issues as and when they crop up within corporate organisations. These refresher courses and training will help directors to update their expertise and technical know-how. Section i (9-11) of the code has clearly made these orientation and training requirements obligatory for directors. Therefore, these orientation and training are no mere cosmetic, but official obligatory programmes in corporations.

Seventhly, Section i (20) of the code has tasked the board chairperson to ensure that the board put up some mechanisms that can be easily implemented to assess board performance, performance of board committees and the performance of board members. This recommendation, if properly executed will go a long way in helping to enhance board effectiveness of publicly-listed corporate organisations. This is because with this assessment, board directors will become more interested in corporate affairs in order to prevent an off-putting evaluation.

Eighthly, the code of best practices has categorically stated that companies should have company secretary as specified in the Companies Code 1963 (Act 179). As a result, Section i (41) lucidly states that the secretary of 
the company has to be a source of counsel and direction to the chairperson and the board in the execution of suitable corporate governance strategies that affect the corporate organisation.

\subsubsection{Shareholder-Related Issues}

It is imperative that shareholders of corporate organisations are properly informed about how their companies are faring in the global market. Accordingly, the 2010 SEC Code has addressed this issue in toto by explicitly stating that boards of corporate organisations have to adopt and implement communication strategies that will enable their managers to clearly reveal and broadcast information in regards to the operation and administration of the corporation to all stockholders irrespective of their holdings (Ghana, 2010). But it is worth considering that in order for shareholders to know what exactly are happening in their corporate organisations, the quality of information corporate authorities covey to them is extremely important. Consequently, the code has unequivocally provided some mechanisms that are required to be implemented by authorities of corporations. These include: communications and reports by the board to stockholders should be in simple language, logical and coherent with past annual reports; the information should be founded on the tenets of even-handedness, rapidity, significance and candidness; and annual reports backed with figures must strive to strike out a steadiness between the helpful and unhelpful facets of the operations of the company for the year under review (Ghana, 2010).

Currently, most shareholders are becoming more interested in seeing how their corporate organisations are helping/assisting other stakeholders in regards to the number of people their companies have employed, the kind of assistance their companies have accorded to the environment they operate in, issues of customer and supplier interests and other social responsibilities. Accordingly, the code has exhaustively addressed this issue in that, aside the financial information that the code directs corporate authorities to convey to shareholders, issues on non-financial information such as jobs; environmental issues, social responsibility, and issues of customer and supplier interests are also to be communicated to shareholders by corporate authorities (Ghana, 2010).

The issue of disclosure, transparency and accountability, which is a hallmark of effective corporate governance, is appropriately addressed in the code of best practices. The code has abundant provisions as to how boards of directors of corporate organisations are to be transparent and accountable to shareholders in carrying out their corporate responsibilities and roles. This will help solve the issue of information asymmetry whereby shareholders, who are owners of corporate organisations, are most a time left out when it comes to information sharing in corporate organisations. One major channel in which this can be done is via the copious reports which the code requires corporate organisations to put in order and send to their stockholders and regulatory bodies within a specific time frame (Ghana, 2010).

\subsubsection{Involvement of Other Stakeholders}

The involvement of other stakeholders in corporate affairs has become an important issue in modern corporations as well as in the current corporate governance debate. The 2010 SEC Code has adequately addressed the issue of the involvement of other stakeholders in corporate affairs. Section i (1.b, p. 12) of the code states that "the interests of other stakeholders are relevant as a derivative of the duty to shareholders". In this period where seismic activities, global warming, climatic change, wars, terrorist activities and so on, have become the order of the day, matters pertaining to environmental and humanitarian challenges have become teething concerns for corporate organisations and governments alike. It is thus pleasant that the code has not overlooked these issues.

\subsubsection{Audit-Related Matters}

Countries across the globe have introduced mechanisms to enhance the independence of auditors and to make tighter their accountability to shareholders (OECD, 2004). It is gratifying to note that the 2010 SEC Code has made provisions for an independent external auditor to ensure "that the audit of the corporate body is conducted in accordance with the generally accepted standards of auditing required by the Institute of Chartered Accountants (Ghana) of its members"'(Ghana, 2010). Also, the role of the external auditor has been overtly stated to include; he/she has to be the main supplier of a factual, impartial, efficient and valuable view on the financial declarations of the corporation; and he/she should adopt assiduousness, objectivity and independence in the discharge of his/her duties and responsibilities (Ghana, 2010).

The issue of external auditor's independence has become a pressing concern to corporate governance experts across the globe. Most international best practices on corporate governance have addressed this issue. The OECD (2004) principle of corporate governance categorically states that:

Provision of nonaudit services by the external auditor to a company can significantly impair their independence 
and might involve them auditing their own work. To deal with the skewed incentives which may arise, a number of countries now call for disclosure of payments to external auditors for non-audit services. Examples of other provisions to underpin auditor independence include, a total ban or severe limitation on the nature of non-audit work which can be undertaken by an auditor for their audit client, mandatory rotation of auditors (either partners or in some cases the audit partnership), a temporary ban on the employment of an exauditor by the audited company and prohibiting auditors or their dependents from having a financial stake or management role in the companies they audit. Some countries take a more direct regulatory approach and limit the percentage of non-audit income that the auditor can receive from a particular client or limit the total percentage of auditor income that can come from one client.

Although not all the provisions that have been stated above are in the code, it is worth noting that the most important of all the provisions, if not arguably, has been unambiguously stated in it. Section iv (92) states that to insure the continuity of effective auditing, persons involved in auditing must be frequently changed or rotated to allow new procedures into the audit work.

It is to a certain extent clear that the code takes the glory for being the most all-inclusive guideline currently in operation in Ghana. Obviously, attempts were made to make sure that its provisions are in accordance with the OECD principles of corporate governance, the CACG principles of corporate governance and best practices of corporate governance in other emergent and transition economies. Therefore, the above discussion provided key issues which are considered as the strengths of the 2010 SEC Code. Undoubtedly, there are other important provisions in the code, but those this paper has extensively discussed are considered the most significant provisions. However, the code has its deficiencies and these are discussed in the next section of this paper.

\subsection{Deficiencies of the 2010 SEC Code}

There are some deficiencies associated with the 2010 SEC Code of best practices of Ghana. For the purpose of this paper, these deficiencies have been grouped under four main sub-headings namely; provisions that lack clarity, substandard provisions, unqualified dereliction and common gaffes.

\subsubsection{Provisions that Lack Clarity}

There are some provisions in the 2010 SEC Code that lack clarity and therefore, become confusing. Some of them conflict with other provisions in the code. Firstly, there is no clarity in regards to the enforcement mechanism provided by the code. In one instance, the code appears to gear towards the "comply-or-explain" model of corporate governance code enforcement, which has become widely-liked or appreciated worldwide. This is typified by the provisions of sections i (14), i (15), ii (51.d), iv (90) and v (94) in the code, which require corporate organisations to declare the extent of their compliance. However, the code also gears towards the professed "rules-based" technique of corporate governance code enforcement. This is typified by the application section of the code, which states that "the Code of Best Practices on Corporate Governance will apply to all corporate bodies approved or licensed as stock exchanges, dealers and investment advisers under the Securities Industry Law, the managers, operators, trustees and custodian of unit trusts and mutual funds and the issuers of publicly traded securities" (p. 12). If the code specifies the minimum guidelines of corporate governance, it means that compliance is obligatory and penalties go along with non-compliance. Another cogent evident that points out that the code veers towards obligation is the provision of section iv (98), which requires that the company's annual report must clearly include a declaration from the board of directors as to the extent of conformity of the firm with the legal and regulatory framework under which it operates and the degree to which payments that are recognised by statute have been fulfilled in regards to the year under review.

Secondly, it is quite fastidious to determine the actual number of documents that the code requires from corporate organisations. An effort to determine the documents requires a searching of the whole range of the provisions of the code. The documents are not jointly listed; instead they exhibit an unpolished style in a baffling vague manner. Certain documents that corporate organisations are supposed to present under the code include documents which are required to be included in their annual reports. Some of these documents are; the corporate governance practices report, material foreseeable risk factors, chairperson's statement on the performance of the corporate organisation, board's statement on the acceptance of responsibility of all information contained in the annual report, management fees, identities of shareholders and the degree of their holdings, associated party transactions, incentive schemes details, fees paid to auditors for audit and non-audit activities, issues pertaining to employees and other stakeholders, and a statement stating the level of conformity with the legal and regulatory framework as stated in the code (Ghana, 2010). Some other documents that the code requires of corporate organisations are the creation of a business code of ethics, its formulation, its monitoring adherence and issues regarding the development of the code of Ethics (Ghana, 2010). In some other cases, it requires a 
considerable effort to ascertain whether a document should be considered single or multiple. For instance, Section iv (102) requires corporate organisations to have their own codes of business ethics that must be implemented as constituent of their governance practices. It is unclear whether a company's statement of business practices and its code of ethics form a single document or multiple documents.

\subsubsection{Substandard Provisions}

There are a number of remarkable provisions in the 2010 SEC Code of best practices, which are substandard in their current state and thus deficient in accomplishing the actual reason for having them. As mentioned earlier, it is praiseworthy that an unambiguous, gentle, modern and detailed definition of the expression "independent directors" can be noticed in the code of best practices (Ghana, 2010). However, the wonderment of this definition arises when one attempts to decipher the rationale for this provision. If there is a provision that requires independent directors to sit on boards of corporate organisations, but does not explicitly state the roles and responsibilities that these directors are to play, then it will lead one to wonder about the rationale behind this provision. Furthermore, the actual number of such directors who are obliged to sit on boards of corporate organisations is not significant. Because of this, it would definitely be a sheer utopian thinking for us to expect these directors to make any meaningful impact on board decisions that will eventually have influence on firm performance. In other jurisdictions, their codes for best practices require these directors to form the majority on the board (UK, 2010) or half of board members are made up of these directors (South Africa, 2009). Also, some of the codes around the globe require that major board committees such as the audit committee (Finnish, 2010; India, 2009; South Africa, 2009; UK, 2010), remuneration committee (Finnish, 2010; India, 2009; UK, 2010) and nomination committee (Finnish, 2010; UK, 2010), are to be entirely made up of independent non-executive directors.

Secondly, as mentioned earlier, the knowledge lacuna pertaining to finance, accounting and basic elements of the laws has been adequately addressed in the code. However, the current state of Section ii (50) has the propensity to prevent whatever benefits Section ii (48) is yearning to accomplish. Section ii (50) has the tendency of resulting into a situation where corporate organisations' finance directors will find their way back to their audit committees. With this oddity, finance directors will be required auditing themselves. It will be called to mind that section i (47) stipulates that the majority of the membership of the board audit committee should be made up of independent non-executive directors. It can be argued that there is a deficiency in Section i (47) of the code. Best practices around the globe require the audit committee to only consist of independent non-executive directors (India, 2009; Singapore, 2012; South Africa, 2009; UK, 2010). Therefore, the possibility of finance directors to be on audit committees is absent. Until section i (47) is amended to mirror the very reason it was suggested, the Securities and Exchange Commission has to be watchful to ensure that corporate organisations are not transmogrified into worse situation even before the creation of the code of best practices; that is, permitting finance directors to sit on audit committees' meetings.

Thirdly, the provision of Section iii (68) requires the board to establish and execute a communication's policy that will make it possible for corporate managers to converse and circulate information pertaining to the running and administration of the firm to stockholders, other stakeholders and the populace. Section iii (69) further states that in respect of quoted companies, this communication policy must be administered by the concept of well-timed and continual disclosure. It is quite surprising that even with these provisions; a lot of listed corporate organisations fail to make their reports available on their official websites. This problem stems from the fact that the code has not stated a definitive medium of communication for companies to publish their annual reports. The Securities and Exchange Commission will have to make sure that this issue is rectified.

\subsubsection{Unqualified Derelictions}

Although there is a wide gamut of provisions in the 2010 SEC Code, there are some important abandoned provisions that should have been integrated into it. Firstly, there are two broadly accepted groups of directors in a corporate organisation; executive directors (consisting of management) and non-executive directors (consisting of outside directors). Whilst the executive directors can organise meetings separately, there is no provision in the code that officially approves that non-executive directors are also entitled to organise separate meetings. These meetings are generally referred to as "executive sessions" (note 1). These "executive sessions" are vitally important in the sense that non-executive directors are supposed to offer constructive criticisms and advice to executive directors. If certain provisions are not stated in the code for such meetings, any effort for non-executive directors to organise such meetings separately will be welcomed with some suspicions from the executive directors. 
Secondly, as mentioned earlier, section i (14) of the code categorically states that preferably, the position of the board chairperson ought to be separated from that of the Chief Executive Officer of the corporate organisation unless there are particular explanations that go against such schism or as perhaps will be in the situation of smaller firms where such separation will be economically imprudent as a result of the cost associated with such division. The code further states the functions of board chairpersons of corporate organisations. However, there is no provision in it that clearly states the roles and responsibilities of CEOs of corporate organisations. Without clear-cut responsibilities of the $\mathrm{CEO}$ in the corporate organisation, the probability that some conflicting issues will arise between the CEO and the board chairperson is high. If some provisions are not lucidly stated in the code, any attempt for boards of directors to perform their functions as monitors and controllers will prove frivolous in that, the $\mathrm{CEO}$ will consider such monitoring as sabotaging.

Thirdly, the code fails to define some terms. For instance, "cross shareholdings" and "key executives". The needfulness to have these terms explained cannot be overlooked. Inasmuch as the code has a section dedicated to explaining technical terms, it would be proper to explain the terms there. If the term "executive" could be explained in that section of the code, then there is no excuse to rationalise the non-explanation of these terms.

\subsubsection{Common Gaffes}

The 2010 SEC Code is not excellent and delightful in all respects. It is characterised by some gaffes. Firstly, it has typographical and grammatical errors such as, improper use of punctuations like hyphens and omission of semi-colon (Ghana, 2010). Secondly, the code is also characterised by poorly constructed phrases, which confuse the actual substance of the provision in which such blunders occur. For instance, the expression "body corporate" could have been properly expressed as "corporate body". Also, the expression "should be accompanies" in section iv (92) could have been properly expressed as "should be accompanied". The expression "with an his capacity" in section i (23.f) could have been appropriately expressed as "with his capacity".

From the aforementioned discussion, it can be argued that these common gaffes do not nullify the importance of the code, but they taint its prominence. It is of extreme relevance that executive, legislative or regulatory instruments are appropriately constructed so that they would be able to communicate the required messages as any mishap could have serious upshots.

\section{Conclusions}

The discussion above undoubtedly reveals that the 2010 SEC Code of best practices of Ghana has the propensity to positively influence corporate governance practice in Ghana. This is because of its extensiveness, comprehensiveness and its compliance with the best practices across the globe. However, compared to other codes around the globe, the code still lags behind in several areas (as specified in our discussion) and certain enhancements are needed to take place. Among the identified deficiencies lies the absence of the roles and responsibilities non-executive directors are to perform. Since there are no clearly defined roles for non-executive directors on the board, they will intend not to pay a particular attention to the running of the company. But in order to curtail this lackadaisical attitude, the study recommends that future revisions of the 2010 SEC code should lucidly state the roles of non-executive directors so that they will be able and eager to exhibit similar commitment to the success of their companies. Basically, non-executive directors are required to offer their ingenious contributions to the board by giving constructive criticisms and counsel. Currently, it has generally been accepted that non-executive directors have a significant role to play to ensuring effective and efficient running of companies (Huse, 2007; Larcker \& Tayan, 2011; Pease \& McMillan, 1993). Therefore, itemizing their roles in the code will enable them to get involved in board activities, which will eventually affect company performance positively.

Gender diversity has become a contemporary issue in regards to corporate board composition. It is currently attracting the necessary attention all over the world. However, the code is deficient in relation to this issue. It is argued that since managerial talent is consistently fragmented across men and women, limiting boards to predominantly include men-if not men only-gets rid of an equally qualified talented group in our societies (Larcker \& Tayan, 2011). This means that women representation on corporate boards might positively influence corporate performance. For instance, women representation on corporate boards can improve board independence by minimising social differences that can compromise boards' independence. Also, women would probably demonstrate higher levels of credibility and teamwork than their counterparts, hence enhancing boardroom discussions. As a result of the benefits that corporations can derive from women representation on their boards, this study recommends that, regulatory bodies such as SEC and GSE ought to work hand-in-hand to 
ensure women representation on boards of listed corporations by including this recommendation on the listing requirements of GSE and future revisions of the 2010 SEC code.

Furthermore, the study recommends that any future revision of the code should include provision(s) in relation to board risk committees. This committee should be entirely made up of independent non-executive directors. It should report directly to the board. Boards of directors of corporate organisations in Ghana should make sure that the risk committee is separately set up from the audit committee. This committee has to have oversight responsibility and advice the entire board on current and future risk strategies. In the advent of advising the board about the amount of risk the company can tolerate, the risk committee should take account of the prevailing as well as potential financial and macroeconomic conditions that are always published by the Ghana Statistical Service, the Bank of Ghana and other research organisations in the country. This attention by the risk committee to the financial environment will perhaps be pertinent for the risk strategies of a company

It is worth considering that since the effectiveness of the code is dependent upon how regulatory bodies-such as the Securities and Exchange Commission and the Ghana Stock Exchange-ensure its enforcement, these bodies are supposed to make sure that the provisions of this code are appropriately reviewed always in order to take into consideration the development of new ideas in corporate management. Furthermore, it is required of these regulatory bodies in Ghana to assist corporate organisations in their effort to comply with the provisions of the code. In addition, these regulatory bodies have to make sure that there are sufficient communication, educational symposiums, seminars, workshops and other equally important educational opportunities to all stakeholders of corporate governance. Lastly, in order to ensure effective enforcement of the provisions spelt out in the code, the enforcement and monitoring divisions of these regulatory bodies must work assiduously. If these regulatory bodies are lethargic in exercising their duties and responsibilities, the code will be but a sheer epistle, dead epistle, we mean. Therefore, it is incumbent on these regulatory bodies to ensure that the provisions that are unambiguously spelt out in the code are effectively implemented.

\section{References}

Berghe, L. A. A. V., \& Levrau, A. (2004). Evaluating Board of Directors: What Constitutes a Good Corporate board? Corporate Governance: An International Review, 12(4), 461-478. http://dx.doi.org/10.1111/j.1467-8683.2004.00387.x

CACG. (1999). Principles for corporate governance in the Commonwealth, CACG guidelines. Retrieved February 1, 2011, from http://www.ecseonline.com/PDF/CACG\%20Guidelines\%20-\%20Principles\%20for\%20Corporate\%20Gove rnance $\% 20$ in $\% 20$ the $\% 20$ Commonwealth.pdf

Cankar, N. K., Deakin, S., \& Simoneti, M. (2010). The Reflexive Properties of Corporate Governance Codes: The Reception of the 'Comply-or-Explain' Approach in Slovenia. Journal of Law and Society, 37(3), 501-525. doi: 10.1111/j.1467-6478.2010.00516.x

EU. (2002). Comparative Study Of Corporate Governance Codes Relevant to the European Union And Its Member States. Retrieved February 2, 2013, from http://ec.europa.eu/internal_market/company/docs/corpgov/corp-gov-codes-rpt-part1_en.pdf

European Corporate Governance Institute (ECGI). Index of All Codes. Retrieved February 1, 2011, from www.ecgi.org/codes/all_codes.php

Finnish. (2010). Corporate Governance Code. Retrieved February 1, 2011, from http://www.ecgi.org/codes/all_codes.php

Ghana. (2010). Corporate Governance Guidelines of Ghana. Retrieved February 1, 2011, from http://www.ecgi.org/codes/all_codes.php

Haskovec, N. (2011). Codes of Corporate Governance: A Review. Retrieved June 18, 2013, from http://www.corpgov.deloitte.com/binary/com.epicentric.contentmanagement.servlet.ContentDeliveryServlet /BrPor/Page\%20Copy/Board\%20of\%20Directors/Codes\%20of\%20Corporate\%20Governance_Yale_05311 2.pdf

Heracleous, L. (1999). Does Singapore Need a Code of Best Practices in Corporate Governance? Singapore Management Review, 21(3), 53-67.

Huse, M. (2007). Boards, Governance and Value Creation: The Human Side of Corporate Governance. New York: Cambridge University Press. http://dx.doi.org/10.1017/CBO9780511611070

India. (2009). Indian Corporate Governance Voluntary Guide. Retrieved February 1, 2011, from 
http://www.ecgi.org/codes/all_codes.php

Italy. (2011). Corporate Governance Code, Retrieved from http://www.ecgi.org/codes/all_codes.php

Larcker, D., \& Tayan, B. (2011). Corporate Governance Matters: A Closer Look at Organizational Choices and Consequences. New Jersey: Pearson Education, Inc.

Millstein, I. R., \& McAVoy, P. W. (2003). The Recurrent Crisis in Corporate Governance. New York: Palgrave MacMillan.

OECD. (2004). The OECD principles of corporate governance. Retrieved February 2, 2011, from http://www.oecd.org/

Ofo, N. (2011). Benchmarking the Code of Corporate Governance in Nigeria 2011 Against Top Ten International Best Practices on Corporate Governance. Retrieved June 18, 2013, from http://papers.ssrn.com/sol3/papers.cfm?abstract_id=1937877

Pease, G., \& McMillan, K. (1993). The Independent Non-Executive Director. Melbourne, Australia: Longman Professional

Singapore. (2012). Code of Corporate Governance. Retrieved March 1, 2013, from http://www.ecgi.org/codes/all_codes.php

South Africa. (2009). King Code of Governance for South Africa 2009 (King III). Retrieved February 1, 2011, from http://www.ecgi.org/codes/all_codes.php

UK. (2010). Corporate Governance Code. Retrieved February 1, 2011, from http://www.ecgi.org/codes/all_codes.php

Werder, A. V., \& Talaulicar, T. (2011). Corporate governance in Germany: basic characteristics, recent developments and future perspectives, In C. A. Mallin (Ed.), Handbook on International Corporate Governance: Country Analyses (2nd ed.). Massachusetts: Edward Elgar Publishing Limited.

\section{Note}

Note 1. "Executive sessions" refer to meetings of the non-executive directors whereby executive directors are intentionally left out. See, UK Corporate Governance Code 2010, sec A.4.1; Brazil's Code of Best Practice of Corporate Governance 2009, sec 2.11; Indian Corporate Governance Voluntary Guidelines 2009, sec I.B.3; and NYSE Listed Company Manual 2003 (as amended), sec 303A.03.

\section{Copyrights}

Copyright for this article is retained by the author(s), with first publication rights granted to the journal.

This is an open-access article distributed under the terms and conditions of the Creative Commons Attribution license (http://creativecommons.org/licenses/by/3.0/). 